\title{
Evaluation of IL28B Gene Sequence Variations in the Diagnosed Null-Response to DAAs Therapy by Intra-PBMCs Nested HCV RNA PCR
}

\begin{abstract}
Ahmed Mohamed Altanbouly ${ }^{1}$ MSc; Mohamed Darwish Ahmed AbdAlla ${ }^{1, *}$ MD ; Hassan Abd EL-Hafiez Rashed $^{1}$ MD; Galal AbdElhameedAbuFarrag ${ }^{1}$ MD; Islam Abdel-Mawla Ammar ${ }^{1}$ MD and Mostafa Kamel EL
\end{abstract} Awady ${ }^{2}$ MD

\section{*Corresponding Author:}

Mohamed Darwish Ahmed AbdAlla darwish0716@azhar.edu.eg

Received for publication Septmber 13, 2020; Accepted January 3, 2021; Published online January 3, 2021.

Copyright 2020 The Authors published by Al-Azhar University, Faculty of Medicine, Cairo, Egypt. All rights reserved. This an openaccess article distributed under the legal terms, where it is permissible to download and share the work provided it is properly cited. The work cannot be changed in anyway or used commercially.

doi: $10.21608 /$ aimj.2021.40774.1313

${ }^{I}$ Hepatology, gastroenterology and infectious diseases Department, Faculty of Medicine, Al-Azhar University, Cairo, Egypt

${ }^{2}$ Molecular Genetics- Department of Microbial Biotechnology National Research center, Cairo, Egypt.

\begin{abstract}
Background: Single nucleotide polymorphisms (SNPs) of the IL28Bgene arereliable predictors of chronic HCV disease course after treatment with Peg-IFN and Ribavirin (RBV).

Aim of work: to detect SNPs in relation tohepatic parenchymal changesin the selected study populations.

Subjects and Methods: Impacts of IL28B-SNPs on the response to direct acting antivirals (DAAs) were evaluated in posttreatment negative serum and cellular HCV-PCR (group I), solitary intra-PBMCs viral infections (group II), and positive HCV-RNA serology (group III). Twelve weeks after completing DAAs-therapy, 45 patients were recruited and divided into three groups $(\mathrm{n}=15 \mathrm{each})$, as afro-mentioned. IL28B-gene sequencing was done to detect SNPs in relation to hepatic parenchymal changes in the selected study populations.

Results: Changes in liver parenchyma of group III (46.7\%) and II (26.6\%) were associated with higherHCV-relapse compared to I $(\mathrm{P}<0.001)$. In normal hepatic parenchyma:the wild-CC sequencewerefrequently identified in group I compared to II and III $(\mathrm{P}<0.001), \mathrm{CT}-\mathrm{SNP}$ was equally distributed in group I and II $(\mathrm{P}=0.34456)$ with significant increases on comparison with III (respectively $\mathrm{P}=0.02391$ and 0.055$)$; $\mathrm{C}$-allele was recognized in group I compared to II $(\mathrm{P}=0.000692)$ and III $(\mathrm{P}=0.000003)$.In cirrhotic liver:TT-SNP was detectedin viremic patients on comparison with infection free $(\mathrm{P}=0.02256)$ and solitaryintra-PBMCsone $(\mathrm{P}=0.08647)$, T-allele was dominant in serologic relapse compared with solitary intracellularinfection $(\mathrm{P}=0.004308)$ and $\mathrm{SVR}$ subjects $(\mathrm{P}=0.000130)$.

Conclusion: Post-DAAs therapy sequencing of IL28B-gene revealed that wild-CC and CT-SNPS are respectively identified in SVR and solitary intra-PBMCS infections when hepatic parenchyma is normal, while TT-SNP and T-alleles are dominant in serologic relapsers with cirrhotic liver.
\end{abstract}

Keywords: IL28B gene; PBMCs PCR; DAAs; HCV Relapse.

Disclosure: The authors have no financial interest to declare in relation to the content of this article. The Article Processing Charge was paid for by the authors.

Authorship: All authors have a substantial contribution to the article.

\section{INTRODUCTION}

Introduction of first and second generations DAAs therapies markedly improved $\mathrm{HCV}$ resistance to treatment and paved the way to evaluate impacts of host related factors that affect $\mathrm{HCV}$ induced liver pathology and therapy response outcomes ${ }^{1,2}$.Positive association of certain IL28B-gene alleles(e.g. Tallele) was found in cirrhotic patients with $\mathrm{CHCV}$ G1 infection in Caucasianpopulations. However, sequencing IL28B-gene in limited numbers of CHCV population from Asia, Latin America or the Middle East with hepatic-cirrhosis was inconclusive ${ }^{3-6}$. The TC IL28B-gene SNP was mainly reported in CHCV liver cirrhosis followed by the TT, while the wild CC genotype was the least reported sequences. ${ }^{7-8}$ The IL28B- geneallele changes or SNPin liver cirrhosis was denied by others .

Spontaneous HCV clearance in addition to favorable response to the INF based therapy were associated with wild IL28B CC gene sequence[10-13]. Contrarily, the wild CC IL28B-gene sequences were reported in association with a higher prevalence of hepatic cirrhosis ${ }^{17,18}$, and raised serum markers of necro-inflammatory hepatic responses to $\mathrm{CHCV}$ infection. ${ }^{6,8,10,14,15}$ The primary immune response to $\mathrm{HCV}$-infection is mediated predominantly through IFN- $\lambda$ cytokines and may be influenced by IL28B genotype ${ }^{16,17}$ There may be an association between frequent presence of IL28B T-allele and developing HCC. ${ }^{18}$

Association of IL28B-gene TT SNP with post-DAAs 
therapy $\mathrm{HCV}$ relapse or resistance, and the wild $\mathrm{CC}$ IL28B-gene with SVR was reported in $2019^{19}$; other researchers found that SVRswere seen more often in $\mathrm{C}$ compared to $\mathrm{T}$ allele ${ }^{20}$. The high cure rate (up to $98 \%$ ) that was reported in many studies is based on clearance of the virus only from serum, not from cells. Positive HCV PBMCs-PCR at 12weeks after end of treatment (EOT) with DAAs was addressed in $<60 \%$ [21-23].The disparity in SVRs outcomes evaluation after testing sera versus PBMCs for $\mathrm{HCV}$ RNA excuses researchers from holding off the IL28B-gene studying that was requested by other investigators ${ }^{24}$.

Goals of the current research included evaluation of IL28B-gene SNPs impacts on response to the direct acting antivirals (DAAs) in the SVR subjects with negative serum and PBMCs-PCR, solitary intraPBMCsHCV viral infections, and positive serum viral RNA-PCR. The results of IL28B-gene sequencing in association with DAAs therapy outcomes were correlated to parenchymal hepatic changes.

\section{Subjects AND MATERIALS}

Patients were recruited from the outpatient's clinic of hepatology, gastroenterology, and infectious diseases at Al-Azhar university specialized hospital. Twelve weeks after end of treatment (EOT) with DAAs, 45 subjects were screened by both serum and PBMCsHCV SRT-PCR and divided into the following equal groups ( $\mathrm{n}=15$ each): group I had negative both serum and PBMCs SRT-PCR,group II with positive PBMCs with negative serum SRT-PCR, and group III had positive serum SRT-PCR.All study subjectsreceived Sofosbuvir at $400 \mathrm{mg}+$ Daclatasvir at $60 \mathrm{mg} \pm$ Ribavirin for 12 weeks according to national guidelines of HCV management at Egypt.

II. SVR status assessment by SRT-PCR for detection of HCV-RNA: HCV-RNA was extracted from serum by using QIAamp Viral RNA Mini Kit (Qiagen artus, Hildenm, German). Total cellular RNA was extracted from the isolated PBMCs using the single-step method that was first published by Chomczynski and Sacchi ${ }^{25}$ and modified later [26$29]$ to detect HCV-RNA in PBMCs. Nested SRTPCR was performed as confirmatory test by using 25 reactions mixture as described before ${ }^{30}$.

III- IL28B Screening Tests:The SNPs on IL28B were identified using a real-time PCR protocol based on the pre-validated TaqMan MGB ${ }^{\mathrm{TM}}$ probe for allelic discrimination assay (Applied Biosystems). Allelic discrimination plots were produced in Statistical Package for The Social Sciences (SPSS version 16.0; SPSS, Chicago, IL).

IV. Evaluation of hepatic parenchymal changes (early fibrosis and late cirrhosis): $\mathrm{CHCV}$ induced liver tissues changes were examined by ultrasonography (US) images and were correlated with Fib4 scoring system in all study populations ${ }^{31}$.

V. Statistics: SPSS 16.0 (IBM; NY, USA) is used to analyze the current data set. $\mathrm{P}<0.05$ indicates significant difference.

\section{RESULTS}

Evaluation of $\mathrm{HCV}$ replication within PBMCs by detecting intracellular antisense RNA-strand.

\begin{tabular}{|c|c|c|}
\hline HCV-RNA Strands & $\begin{array}{r}\text { Group II } \\
(\mathbf{n = 1 5})\end{array}$ & $\begin{array}{r}\text { Group III } \\
(\mathbf{n}=\mathbf{1 5})\end{array}$ \\
\hline Sense and antisense & & \\
strands & $9(60.00 \%)$ & $9(60.00 \%)$ \\
Antisense strand & $2(13.33 \%)$ & $3(20.00 \%)$ \\
only & & \\
\hline Sense strand only & $4(26.67 \%)$ & $3(20.00 \%)$ \\
\hline P value & 0.02683773 & 0.00281433 \\
\hline
\end{tabular}

Table 1: Recognition of viral RNA sense and antisense strands within PBMCs of viral relapsers regardless to viremic status

Significant viral replication within PBMCs of HCV relapses regardless to the status of serum SRT-PCR $(\mathrm{P}<0.05)$.Intracellular-antisense strands presents a solid prove of viral replication in group II and III.

Correlation of IL28B-gene SNPs with liver parenchymal changes as described by hepatic ultrasonographic image and Fib4-scores. 


\begin{tabular}{|c|c|c|c|c|c|c|c|c|c|}
\hline \multirow{2}{*}{} & \multicolumn{3}{|c|}{ Normal (n=13) } & \multicolumn{3}{c|}{ Bright (n=21) } & \multicolumn{3}{c|}{ Coarse (n=11) } \\
\cline { 2 - 10 } & CC & CT & TT & CC & CT & TT & CC & CT & TT \\
\hline Group I & $5(38 \%)$ & $4(31 \%)$ & $0(0 \%)$ & $0(0 \%)$ & $3(14 \%)$ & $3(14 \%)$ & $0(0 \%)$ & $0(0 \%)$ & $0(0 \%)$ \\
\hline Group II & $0(0 \%)$ & $3(23 \%)$ & $1(8 \%)$ & $1(4.5 \%)$ & $4(19 \%)$ & $2(9.5 \%)$ & $3(27 \%)$ & $0(0 \%)$ & $1(9 \%)$ \\
\hline Group III & $0(0 \%)$ & $0(0 \%)$ & $0(0 \%)$ & $2(9.5 \%)$ & $4(19 \%)$ & $2(9.5 \%)$ & $1(9 \%)$ & $2(1.8 \%)$ & $4(3.6 \%)$ \\
\hline P Value: I vs II & 0.0098 & 0.34456 & 0.250 & 0.250 & 0.352 & 0.336 & 0.054 & 0.250 & 0.25000 \\
\multicolumn{1}{|c|}{ I vs III } & 0.0098 & 0.02391 & 0.250 & 0.122 & 0.473 & 0.336 & 0.250 & 0.119 & 0.02256 \\
II vs III & 0.250 & 0.05500 & 0.250 & 0.308 & 0.500 & 0.500 & 0.169 & 0.119 & 0.08647 \\
\hline
\end{tabular}

Table 2: Single nucleotide polymorphism (SNPs) of IL28-gene in relation to ultrasonographic hepatic image variations

The wild type sequences (CC) of IL28B-gene was seen more often in association with normal hepatic parenchyma in group I compared to group II and III $(\mathrm{P}<0.01)$. The CT SNP of IL28B gene were equally detected in both group I and II (P>0.3)with significant detection on comparison with group III (respectively, $\mathrm{P}=0.02391$ and 0.055$)$ when liver tissues had normal US image. The TT SNP was only recognized in viremic patients (group III) in association with liver cirrhosis on comparison with Group I ( $\mathrm{P}=0.02256)$ and group II $(\mathrm{P}=0.08647)$.

\begin{tabular}{|l|c|c|c|c|c|c|c|c|c|}
\hline \multirow{2}{*}{} & \multicolumn{3}{|c}{ Fib4:<1.45 (n=13) } & \multicolumn{3}{c|}{ Fib4:1.45-3.25 (n=20) } & \multicolumn{3}{c|}{ Fib4:>3.25 (n=12) } \\
\cline { 2 - 11 } & CC & CT & TT & CC & CT & TT & CC & CT & TT \\
\hline Group I & $1(7.6 \%)$ & $2(15.3 \%)$ & $1(7.6 \%)$ & $4(20 \%)$ & $3(15 \%)$ & $2(10 \%)$ & $0(0 \%)$ & $2(16.6 \%)$ & $0(0 \%)$ \\
\hline Group II & $2(15.3 \%)$ & $1(7.6 \%)$ & $0(0 \%)$ & $2(10 \%)$ & $4(20 \%)$ & $2(10 \%)$ & $0(0 \%)$ & $2(16.6 \%)$ & $2(16.6 \%)$ \\
\hline Group III & $0(0 \%)$ & $4(30.7 \%)$ & $2(15.3 \%)$ & $1(5 \%)$ & $1(5 \%)$ & $1(5 \%)$ & $2(16.6 \%)$ & $1(8.3 \%)$ & $3(25 \%)$ \\
\hline P Value: I vs II & 0.305 & 0.305 & 0.260 & 0.211 & 0.352 & 0.500 & 0.192 & 0.500 & 0.119 \\
\multicolumn{1}{|c}{ I vs III } & 0.260 & 0.201 & 0.305 & 0.097 & 0.178 & 0.308 & 0.119 & 0.304 & 0.054 \\
\cline { 2 - 9 } II vs III & 0.120 & 0.090 & 0.120 & 0.308 & 0.097 & 0.308 & 0.119 & 0.304 & 0.329 \\
\hline
\end{tabular}

Table 3: Single nucleotide polymorphism (SNPs) of IL28-gene in relation to various ranges of Fib4-scores values

Only TT SNP of IL28B-gene showed close to significantly increased frequency in viremic patients who had Fib4 score $>3.25$ when compared to group I $(\mathrm{P}=0.054)$. In the rest of Fib4-score results, wild and SNPs sequences of the same gene had no correlation with all grades of hepatic parenchymal changes in all groups $(\mathrm{P}>0.09)$.

Correlation of IL28B-gene alleles with liver parenchymal changes as evaluated by hepatic ultrasonographic imageand Fib4-scores. 


\begin{tabular}{|c|c|c|c|c|c|c|}
\hline & \multicolumn{2}{|c|}{ Normal $(n=26)$} & \multicolumn{2}{|c|}{ Bright $(n=42)$} & \multicolumn{2}{|c|}{ Coarse $(n=22)$} \\
\hline & $\mathbf{C}$ & $\mathbf{T}$ & $\mathrm{C}$ & $\mathbf{T}$ & $\mathrm{C}$ & $\mathbf{T}$ \\
\hline Group I & $14(53.9 \%)$ & $4(15.4 \%)$ & $3(7.10 \%)$ & $9(21.4 \%)$ & $0(0.0 \%)$ & $0(0.0 \%)$ \\
\hline Group II & $3(11.5 \%)$ & $5(19.2 \%)$ & $6(14.3 \%)$ & $8(19.0 \%)$ & $6(27.3 \%)$ & $2(9.1 \%)$ \\
\hline Group III & $0(0.0 \%)$ & $0(0.0 \%)$ & $8(19.0 \%)$ & $8(19.0 \%)$ & $4(18.2 \%)$ & $10(45.5 \%)$ \\
\hline P Value: Ivs II & 0.000692 & 0.366351 & 0.1595665 & 0.397003 & 0.005285 & 0.122093 \\
\hline I vs III & 0.000003 & 0.027611 & 0.0 .06070 & 0.397003 & 0.026943 & 0.000130 \\
\hline II vs III & 0.058824 & 0.012655 & 0.287791 & 0.500000 & 0.250273 & 0.004308 \\
\hline
\end{tabular}

Table 4: IL28B-gene alleles nucleotide polymorphism in relation to ultrasonographic hepatic image variations

In normal hepatic parenchyma $\mathrm{C}$ allele was more seen in group I compared togroup II ( $\mathrm{P}=0.000692)$ and group III $(\mathrm{P}=0.000003)$; the $\mathrm{T}$ allele wasdetected more often in intracellular HCV RNA relapserscompared to serologic relapse $(\mathrm{P}=0.012655)$. In cirrhotic patients the $\mathrm{T}$ allele was dominant in serologic relapses (group III) compared with cellular relapse $(\mathrm{P}=0.004308)$ and SVR subjects $(\mathrm{P}=0.000130)$; the $\mathrm{C}$ allele was recognized $(27.35 \%)$ in intracellular relapsers compared to SVR subjects $(\mathrm{P}=0.005285)$.

\begin{tabular}{|l|c|c|c|c|c|c|}
\hline \multirow{2}{*}{} & \multicolumn{2}{|c|}{ Fib4: $<1.45(n=26)$} & \multicolumn{2}{c|}{ Fib4:1.45-3.25 (n=40) } & \multicolumn{2}{c|}{ Fib4: >3.25 (n=24) } \\
\cline { 2 - 7 } & C & T & C & T & C & T \\
\hline Group I & $4(15.3 \%)$ & $4(15.3 \%)$ & $11(27.5 \%)$ & $7(17.5 \%)$ & $2(8.3 \%)$ & $2(8.3 \%)$ \\
\hline Group II & $5(19.2 \%)$ & $1(3.8 \%)$ & $8(20 \%)$ & $8(20 \%)$ & $2(8.3 \%)$ & $6(25 \%)$ \\
\hline Group III & $4(15.3 \%)$ & $8(30.7 \%)$ & $3(7.5 \%)$ & $3(7.5 \%)$ & $5(20.8 \%)$ & $7(29.1 \%)$ \\
\hline P Value: I vs II & 0.366351 & 0.100000 & 0.223343 & 0.391967 & 0.50000 & 0.073185 \\
\multicolumn{1}{|c|}{ I vs III } & 0.500000 & 0.105334 & 0.010796 & 0.099526 & 0.12823 & 0.039783 \\
\multicolumn{1}{|c|}{ II vs III } & 0.366351 & 0.006369 & 0.060071 & 0.060071 & 0.12823 & 0.379271 \\
& & & & & & \\
\hline
\end{tabular}

Table 5: IL28B-gene alleles nucleotide polymorphism in relation to various ranges of Fib4-scores values

$\mathrm{T}$ allele was found in group III in association with high (Fib4:>3.25) or low (Fib4:<1.45) scores when respectively compared to group II $(\mathrm{P}=0.006369)$ and group I $(\mathrm{P}=0.039783)$. The group I was associated with frequent identification of C-allele within the intermediate score (Fib4:1.45-3.25) when compared with group III $(\mathrm{p}=0.010796)$.

\section{DISCUSSION}

IL28B-gene sequencing showed different patterns of SNPs distribution that effectively play an obvious role in determiningpost Peg-INF treatment outcomes $^{11,15}$.The rules of host IL28B-gene sequences variation in post-DAAs therapy of $\mathrm{CHCV}$ infections are still debatable because of the qualification of the used diagnostic procedure that evaluate viral relapses ${ }^{19,23}$. The sustained virologic response (SVR) is recognized at the end of the 12th week after treatment when serum HCV-PCR is negative. Other researchers debated the definition of both relapse and SVR, as PBMCs-PCR was added to the diagnostic battery for detection of the intracellular HCV-RNA persistent infection 25, 30 .Overtime follow up of both naïve and experienced patients with positive intra-PBMCs HCV-RNA infection, but negative serum PCR, is associated with viral seroconversion ${ }^{26}$.

In the current research, the SVR (group I) had negative serum and cellular HCV-PCR, while relapsers (group III) had positive serum HCV SRTPCR at the EOT. We added a third liability group of patients (group II) who had solitary intra-PBMCs HCV RNA at EOT, mostly antisense RNA-strand as a clue of active viral replication and addressed them 
as cellular relapsers, as previously documented by other researchers ${ }^{21-23}$.

A distinct relationship between the IL28-gene SNPs with both HCV relapse and liver parenchymal changes is elaborated in our research. In patients who had normal liver parenchyma, we found high frequencies of the wild CC sequences in the SVR, and CT-SNP in persistent solitary intra-PBMCs HCV infection. The TT-SNPs of the IL-28 gene wereseen more often in HCV serologic relapsers after DAAs therapy when patients have cirrhotic liver. Conclusions from the previouslypublished research that reported positive ${ }^{3-8}$ or negative ${ }^{9}$ correlations of IL28B-gene SNPs with anti-HCV treatment outcomes are not matching the current study, because of using cellular HCV-PCR in case selection during the current research.

$\mathrm{CHCV}$ infection is almost always associated with hepatic pathology that ranges from hepatic stiffness and fibrosis to a full-blown liver cirrhosis ${ }^{31}$. It seems that occurrence of hepatic cirrhosis in response to $\mathrm{CHCV}$ infection would be switched on as a result of the already existent SNPs of some known and mostly unknown genes with subsequent association with viral relapses. Furthermore, the fact that $\mathrm{CHCV}$ infection causes liver cirrhosis in a small fraction of the affected population deviates attention to host specific factors. Extended research should be designed to study the relationship between gene SNPs and occurrence of various grads of hepatic parenchymal changes; as it has been difficult to reach posttreatment SVR of CHCV infection regardless to the used therapeutic regimens on using $\mathrm{HCV}$ cellular-PCR in evaluation ${ }^{21-23}$.

Pretreatment identification ofthe IL28-gene wild (CC) andSNPs (CT or TT) sequences in relation to liver parenchymal changes before starting DAAs therapy inCHCV infection wouldpredict one of the following: a.full clearance of the virus (CC) in those with normal liver parenchyma $b$. persistence of solitary intra-PBMCs infections (GT) in close to normal hepatic tissues rather than liver fibrosisc.full serologic relapses (TT) in established liver cirrhosis.

\section{CONCLUSION}

the post-DAAs treatment sequencing of IL28B-gene showsconsiderable relationships with the end of treatment (EOT) results. The wild-CC and CT-SNP sequences are respectively identified in SVR and solitary intra-PBMCS HCV-infections in association with normal hepatic parenchyma. The TT-SNP and T alleles are dominant in serologic relapsers with liver cirrhosis. We strongly recommend pre-DAAs treatment screening for the IL28-gene SNPs on large scales studies to further confirm the above-mentioned conclusions.

\section{REFERENCES}

1- Coppola N, Pisaturo M, and Sagnelli C, et al. Role of genetic polymorphisms in hepatitis $\mathrm{C}$ virus chronic infection. World Journal of Clinical Cases: WJCC 2015; 3:807-22.

2- Vasilios P.and Stylianos K. Current status and emerging challenges in the treatment of hepatitis $\mathrm{C}$ virus genotypes 4 to 6 , World J Clin Cases 2015 March 16; 3:210-20.
3- Mangia A, De Ledinghen V, and Bailly F, et al. IL28B genotype is associated with cirrhosis or transition to cirrhosis in treatment-naive patients with chronic HCV genotype 1 infection: the international observational Gen-C study. SpringerPlus 2016; 5:1-13.

4- Fabris C, Falleti E, and Cussigh A, et al. IL-28B rs $12979860 \mathrm{C} / \mathrm{T}$ allele distribution in patients with liver cirrhosis: role in the course of chronic viral hepatitis and the development of HCC. J Hepatol 2011; 54:716-22.

5- Falleti E, Bitetto D, and Fabris C, et al. Role of interleukin $28 \mathrm{~B}$ rs $12979860 \mathrm{C} / \mathrm{T}$ polymorphism on the histological outcome of chronic hepatitis $\mathrm{C}$ : relationship with gender and viral genotype. J Clin Immunol 2011; 31:891-9.

6- Noureddin M, Wright EC, and Alter HJ, et al. Association of IL28B genotype with fibrosis progression and clinical outcomes in patients with chronic hepatitis $\mathrm{C}$ : a longitudinal analysis. Hepatology 2013; 58:1548-57.

7- Shousha HI, Awad AH, and Omran DA, et al. Data mining machine learning algorithms using IL28B genotype and biochemical markers best predicted advanced liver fibrosis in chronic HCV. Japanese journal of infectious diseases, 2018;71:51-7.

8- D'Ambrosio R, Aghemo A, and De Francesco R, et al. The association of IL28B genotype with the histological features of chronic hepatitis $\mathrm{C}$ is $\mathrm{HCV}$ genotype dependent. Int J Mol Sci 2014; 15:721324.

9- Marabita F, Aghemo A, and De Nicola S, et al. Genetic variation in the interleukin-28B gene is not associated with fibrosis progression in patients with chronic hepatitis $\mathrm{C}$ and known date of infection. Hepatology 2011; 54:1127-34.

10- Bochud PY, Bibert S, and Kutalik Z, et al. IL28B alleles associated with poor hepatitis $\mathrm{C}$ virus (HCV) clearance protect against inflammation and fibrosis in patients infected with non-1 HCV genotypes. Hepatology 2012; 55:384-94.

11- Di Marco V, Bronte F, and Calvaruso V, et al. (2012). IL28B polymorphisms influence stage of fibrosis and spontaneous or interferon-induced viral clearance in thalassemia patients with hepatitis C virus infection. Haematologica 2012; 97:679-86

12- Ge D, Fellay J, and Thompson AJ, et al. Genetic variation in IL28B predicts hepatitis C treatmentinduced viral clearance. Nature 2009; 461:399-401.

13- Thomas DL, Thio CL, and Martin MP, et al. Genetic variation in IL28B and spontaneous clearance of hepatitis C virus. Nature 2009; 461:798-80.

14- Abe H, Ochi H, and Maekawa T, et al. Common variation of IL28 affects gamma-GTP levels and 
inflammation of the liver in chronically infected hepatitis C virus patients. J Hepatol 2010; 53:43943.

15- Rembeck K, Alsiö A, and Christensen PB, et al. Impact of IL28B-related single nucleotide polymorphisms on liver histopathology in chronic hepatitis C genotype 2 and 3. PLOS ONE 2012; 7:e29370.

16- Thomas E, Gonzalez VD, and Li Q, et al. HCV infection induces a unique hepatic innate immune response associated with robust production of type III interferons. Gastroenterology 2012; 142:978-88.

17- Watanabe T, Sugauchi F, and TanakaY, et al. Hepatitis $\mathrm{C}$ virus kinetics by administration of pegylated interferon- $\alpha$ in human and chimeric mice carrying human hepatocytes with variants of the IL28B gene. Gut 2013; 62:1340-46.

18- Zhang Y, Zhu SL, Chen J, and Li LQ. Metaanalysis of associations of interleukin-28B polymorphisms rs8099917 and rs12979860 with development of hepatitis virus-related hepatocellular carcinoma. Onco Targets Ther 2016; 9:3249-57.

19- Khan AJ, Saraswat VA, and Ranjan P, et al. Polymorphism in interferon $\lambda 3$ /interleukin-28B gene and risk to noncirrhotic chronic hepatitis $\mathrm{C}$ genotype 3 virus infection and its effect on the response to combined daclatasvir and sofosbuvir therapy. Journal of medical virology 2019; 91:65967.

20- Salum GM, Dawood RM, and El-Meguid MA, et al.Correlation between IL28B/TLR4 genetic variants and HCC development with/without DAAs treatment in chronic $\mathrm{HCV}$ patients. Genes \& Diseases 2019; 5:1-9.

21- Hanno AF andMohiedeen KM. HCV RNA in peripheral blood mononuclear cells (PBMCs) as a predictor of the response to antiviral therapy in chronic hepatitis C. Alexandria Journal of Medicine 2014; 50:317-22.

22- ElzahabyAA, Soliman GM, and Korany MA, et al.Association Between Post Treatment Existence Of HCV/ RNA Positive Strand And/Or Negative Strand In The PBMCsand HCV Relapse.Journal of the Egyptian Society of Parasitology 2017; 47:32330.

23- Abd Alla MDA, Dawood RM, and Rashed H, et al. Treatment of Hepatitis C virus (HCV) by Direct Acting Antivirals (DAAs) Plus Ribavirin Eliminates Intra-Peripheral Blood Mononuclear Cells (PBMCs) Viral RNA and Reduces Virologic Relapse in Diverse Hepatic Parenchymal Changes. Submitted to Archives of Virology in May 2020. Manuscript revision is still in progress. Submission Number: ARVI-D-20-00378R1.
24- HashmiAH, Husnain MA, and Farooq A, et al. IL28B is An Irrelevant Prognostic Factor for HCV in the Era of Highly Effective DAAs. J VirolAntivir Res 2018; 7:1-4.

25- Chomczyński P and Sacchi N. Single-step method of RNA isolation by acid guanidinum thiocyanatephenol-chlotoform extraction. Anal Biochem 1987; 162:156-9.

26- Abd Alla MDA and El-Awady MK. Hepatitis C virus RNA strands detection in peripheral blood mononuclear cells legitimizes virus eradication in negative serum PCR naïve and post-treatment patients. J Clin \&TranslHepatol 2017;5:1-8.

27- Zaman N, Asad MJ, and Raza A, et al. Presence of HCV RNA in peripheral blood mononuclear cells may predict patient"s response to interferon and ribavirin therapy. Ann Saudi Med 2014; 34:401-6.

28- Abd Alla MDA, Elibiary SA, and Wu GY, et al. Occult HCV infection (OCI) diagnosis in cirrhotic and non-cirrhotic naïve patients by intra-PBMC nested viral rNA PCR. J Clin \& TranslHepatol, 2017; 5:319-26.

29- Abd Alla MDA, El Awady MK, and Dawood RM, et al. Hepatitis C virus serologic relapse after treatment with direct-acting antivirals is dependent on viral RNA levels in peripheral blood mononuclear cells and the grade of liver cirrhosis. Archives of virology 2018; 163:2765-74.

30- El-Awady MK, Abdel Rahman MM, Ismail SM, et al. Prediction of relapse after interferon therapy in hepatitis $\mathrm{C}$ virus-infected patients by the use of triple assay. J Gastroenterol Hepatol 2003; 18:6873.

31- Wahab EA, Fathy T, and Saber S, et al. Hepatic Elastography And Fib-4 Score Versus Liver Biopsy For Assessment Of Liver Fibrosis In Chronic Hcv Patients. Zagazig University Medical Journal 2017; 21:1-11. 